IRA-International Journal of Management \& Social Sciences

ISSN 2455-2267; Vol.04, Issue 02 (2016)

Pg. no. 324-338

Institute of Research Advances

http://research-advances.org/index.php/RAJMSS

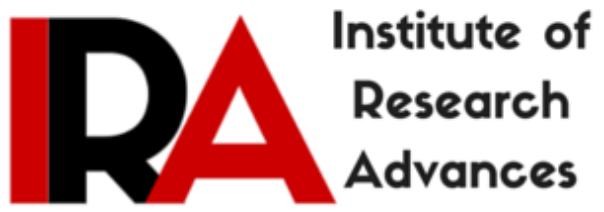

\title{
Women Empowerment through Self-help Groups (SHGs): Cases from Telangana State
}

\author{
Dr. Shankar Chatterjee \\ Professor \& Head (CPME) \\ NIRD \&PR, Rajendranagar, \\ Hyderabad-500 030 \\ Telangana, India.
}

Type of Review: Peer Review

DOI: http://dx.doi.org/10.21013/jmss.v4.n2.p3

\section{How to cite this paper:}

Chatterjee, S. (2016). Women Empowerment through Self-help Groups (SHGs): Cases from Telangana State. IRA-International Journal of Management \& Social Sciences (ISSN 2455-2267), 4(2), 324-338. doi:http://dx.doi.org/10.21013/jmss.v4.n2.p3

(C) Institute of Research Advances

(cc) BY-NC

This work is licensed under a Creative Commons Attribution-Non Commercial 4.0 International License subject to proper citation to the publication source of the work.

Disclaimer: The scholarly papers as reviewed and published by the Institute of Research Advances (IRA) are the views and opinions of their respective authors and are not the views or opinions of the IRA. The IRA disclaims of any harm or loss caused due to the published content to any party. 


\begin{abstract}
This article is based on field study carried out in June 2016 in Nizamabad District of Telangana where it was observed that rural women belonging to all categories of caste with primary education or even illiterate under the banner of self-help groups (SHGs) had been earning not only income but feeling empowered. Almost all were below poverty line $(B P L)$ once upon a time and few during the course of study were also were BPL. Regrading, empowerment, it was reported that almost all women were attending gram sabha meeting and sharing their views. Even it was reported that all freely talk to bank managers, block officials and others. In this article few cases are presented based on field study.
\end{abstract}

Key words: BPL, empowerment, income, Nizamabad and SHG.

This research paper deals with how self-help groups (SHGs) have facilitated to improve economic condition of below poverty line (BPL) women who mostly belonged to below poverty line households and thus they felt empowered as their husbands used to take their suggestions for family matters. Based on the field study carried out time to time, the author has presented few cases drawn from Nizamabad district of Telangana. Before discussing the cases, few lines about women empowerment may be highlighted here.

\title{
Women empowerment: Meaning
}

Women empowerment means emancipation of women from the vicious grips of social, economic, political, caste and gender-based discrimination. It means granting women the freedom to make life choices. Women empowerment does not mean 'deifying women' rather it means replacing patriarchy with parity. In this regard, there are various facets of women empowerment, are:

Human Rights or Individual Rights, Human Rights or Individual Rights, Social Women Empowerment, Educational Women Empowerment, Economical and occupational empowerment, Legal Women Empowerment, Political Women Empowerment (.iaspaper.net/women-empowerment) In this regard Swami Vivekananda may be quoted "There is no chance for the welfare of the world unless the condition of women is improved. It is not possible for a bird to fly on only one wing." Inclusion of "Women Empowerment' was one of the primary objectives in the eight Millennium Development Goals.

According to UNDP Report, 2013 "Unless people can participate meaningfully in the events and processes that shape their lives, national human development paths will be neither desirable nor sustainable. People should be able to influence policymaking and results, and young people in particular should be able to look forward to greater economic opportunities and political participation and accountability".

The author has observed that self-help groups (SHGs) have facilitated to improve economic development of below poverty line (BPL) women. Based on the filed study the author has presented few cases drawn from different parts of the country. And before discussing the cases the meaning of self-help group is presented here. According to FAO, SHG is "An informal association of individuals formed to accomplish certain objectives". Further, "An association whose members agree to work together for common objective. Donors and the Governments organize SHGs as a means of development".

\section{Cases Pertaining to Women Empowerment:}

These cases studied in Nizamabad district of Telangana bin June 2016 by the author reflects the grass root reality how women have felt empowered when their economic condition improved by joining in the SHG and borrowing from different sources including from SHG's corpus fund. 


\begin{abstract}
About the district:
Nizamabad district is located in the north-western region of Telangana state, India with its headquarters as also in Nizamabad city. The district has three municipalities and a Corporation in Nizamabad. As found from statistics that Nizamabad is one of the smallest and least populous district in Telangana. Further, Nizamabad city is $3^{\text {rd }}$ largest city after Hyderabad and Warangal. The district has an area of 7,956 square kilometres with a population of 2,552,073 of which 23.06 percent live in urban areas. The total population is roughly equal to the nation of Kuwait or the US state of Nevada. This gives it a ranking of $165^{\text {th }}$ in India (out of a total of 640 districts).The district has a population density of 321persons per square kilometre (wiki/nizamabad_district). A few of the important particulars about the district are presented in table-1.
\end{abstract}

Table: 1 Few socio-economic particulars about Nizamabad district

\begin{tabular}{|l|l|l|}
\hline Particular & $\mathbf{2 0 1 1}$ & $\mathbf{2 0 0 1}$ \\
\hline Total Population & $2,551,335$ & $2,345,685$ \\
\hline Male & 1,250641 & $1,162,905$ \\
\hline Female & $1,300,694$ & $1,182,780$ \\
\hline Population Growth & $8.77 \%$ & $15.12 \%$ \\
\hline Area in Sq. Kms. & 7,956 & 7,956 \\
\hline Density per square Kilometre & 321 & 295 \\
\hline Sex ratio (Per 1000) & 1040 & 1017 \\
\hline Child Sex ratio (0-6 Age) & 948 & 959 \\
\hline Average Literacy & 61.25 & 52.02 \\
\hline Male Literacy & 71.47 & 64.91 \\
\hline Female Literacy & 51.54 & 39.48 \\
\hline
\end{tabular}

Source: www.census2011.co.in/census/district/nizamabad.html

Although the table is self-explanatory but it may be noted that:

$>$ The female population is more than the male population.

$>$ Population growth has come down in 2011 than that of 2001.

$>$ The child sex ratio has also declined in 2011 than 2001.

$>$ The female literacy is at low level as all India average in this regard was 65.46 percent and in Kerala, the same was 92 percent.

\title{
Women empowerment through SHG:
}

In Nizamabad district self-help groups (SHG) are the powerful instrument for women empowerment. While the study was carried out in June 2016, the district officials reported that altogether there were around 41, 000 SHGs in the district spread over to 1540 Village Organisations (VOs) with total members of 4.28 lakh and all belonged to women. No one stays inside of the house as all participate meetings whether gram sabha or any other. Based on the study, few cases of women entrepreneurs who felt empowered after joining in the SHG vis-à-vis earning of income by borrowing loans are presented here. The study was carried out at Navipet mandal of the district in June 2016.

\section{Cases based on Field Study:}

Case 1:

This classic case shows how a young woman can be a dynamic entrepreneur if provided with minimum bank loan or petty loan. Even in interior rural areas of our country such potentiality exists among the women. This is the case of Mrs. N. Laxmi, 37 years age studied up to $5^{\text {th }}$ standard having 3 children - 2 male and 1 female - has shown how one can be dynamic and can earn decent income. And thus can be felt empowered as with decent earning one can be empowered only. Her husband as mason was earning meagre income, which was not adequate to sustain five members family. As sequel she decided to start petty business. In the year 1999, she along with other nine women, i.e. altogether 10 women (three of whom were Muslim, seven Backward Community) formed Maheswari Mahila self- help group (SHG) at Navipet village of Navipet Mandal. Each member of the SHG 
initially (1999) was saving at the rate of Rs. 30 per month, which in 2004 was enhanced to Rs.50 per month and later on in 2008 it was increased to Rs.100. Mrs. Laxmi was involved with bangle, tailoring and cloth business. The other members were involved in different activities, like pickle making, bidi rolling (local cigarette) and even five members' husbands were daily wage earners. She (Mrs. Laxmi) started her tailoring training trade by taking bank loan and also SHGs loan from the corpus fund. Later on started cloth and bangle business by taking loan from two other sources viz. SthreeNidhi and from Village Organization (V.O). It is pertinent to mention that SthreeNidhi credit cooperative Federation Ltd., is promoted by the Telangana Government and the Mandal Samkahyas to supplement credit flow from banking sector and is a flagship programme of the Government. SthreeNidhi provides timely and affordable credit to the poor SHG members for poverty alleviation (streenidhi.telangana.gov.in). Among her many activities pickle making was also one which she used to prepare and sell in local market. In addition, she by preparing local snacks sends to abroad also. While study was carried out in June 2016 she informed that she borrowed five times from bank (Union Bank of India) ranging from Rs.10,000 to Rs.50,000. During the course of study her loan outstanding was Rs.22,000, out of Rs.50,000. Regarding SthreeNidhi loan, she borrowed from two sub sources - one as normal loan of Rs.25,000 (borrowed in February 2015) where outstanding amount was Rs.11,270 and another loan meant for income generation activities amounting to Rs.50,000 (in March 2016), where outstanding amount was Rs.46,000. Her SHG loan ranged from minimum of Rs.500 to Rs.10,000 spread over to four times and last loan of Rs10,000 was drawn in August 2015 amounting to Rs.10,000 where outstanding amount was Rs.4,000.

Her fourth source of loan was from Village Organisation (V.O.). In this case also she took four times loan which was in between Rs.5,000 (minimum) and Rs.50,000 maximum. The last dose of Rs.50,000 loan she took in September 2014, where outstanding amount was Rs.15,000.

During the course of discussion, she informed that she had been doing the business from her own building as a result she need not pay any rent etc. Further, she informed that the family did not have any agricultural land. With all these activities, according to her monthly income was hovering around Rs.15,000 after repaying of bank loan etc. Of course income of her husband was not taken into account. As sequel she informed that she felt empowered and many times her husband took her guidance in family matters. Further, many young women of the village and its vicinity take her suggestion and guidance also.

\section{Case2:}

This case pertains to Ms. Arundathi, 36 years of age member of Gayathri Mahila SHG of Jannepally of Navipet mandal, Nizamabad district. She, in order to support, her family started a petty shop i.e. grocery cum general store by borrowing money from different sources. Her loans were from four sources viz. SHG loan (internal loan from SHG's corpus fund) of Rs. 30,000 (total loan borrowed in several occasions). Secondly, her bank loan consisted of four doses $-1^{\text {st }}$ dose Rs. 5,000, $2^{\text {nd }}$ dose Rs. $30,000,3^{\text {rd }}$ dose 50,000 and $4^{\text {th }}$ dose was to the tune of Rs.75,000. In addition, she also borrowed from Village Organisation's (V.O.) general fund (which can be termed as third source) amounting to Rs. 45,000 and fourth source was SthreeNidhi loan $-1^{\text {st }}$ loan was Rs. 25,000 and $2^{\text {nd }}$ loan Rs.50,000 and thus her total borrowing from all the sources, as mentioned, was Rs. 2,60,000. Her monthly net income was in the range of Rs. 10,000 to 13,000 from all the activities. Here, husband's income was not taken into account.

\section{Case 3:}

Ms. Mamatha, a young entrepreneur of 34 years was member of Shiva Sai Mahila SHG and the resident of Jannepally village, Navipet mandal. She after studying backward and forward linkages mainly forward linkage decided to start a hotel where meals as well as tiffin would be available and accordingly started the trade, later on started fast food selling. She also borrowed from several sources which in nutshell is presented here. 
She borrowed from SHG's corpus fund amounting to Rs. 30,000 (several times she took loan). Her bank loans were $-1^{\text {st }}$ dose Rs. 5,000, $2^{\text {nd }}$ dose Rs. $15,000,3^{\text {rd }}$ dose Rs. 50,000, $4^{\text {th }}$ dose Rs. 50,000 and $5^{\text {th }}$ dose was also Rs. 50,000. She also borrowed from Village Organisation totalling to Rs. 50,000 and SthreeNidhi loan of Rs 50,000. Thus, her total amount of loan borrowed from all the sources was to the tune of Rs. 2,70,000. She individually was earning from all the sources in between Rs. 15,000 and Rs. 18,000 per month.

\section{Case 4:}

Ms. Uma (39 years) belonged to Thirumala Mahila SHG of Navipet village of Navipet mandal. Her prowess was in tailoring as sequel she decided to start tailoring and cloth business. Like other women, she also borrowed from several sources for setting up as well as expand her business. These were - a) SHG's loan (internal borrowing in several occasions) totalling to Rs. 40,000, b) bank loans $-1^{\text {st }}$ dose Rs. 5,000, $2^{\text {nd }}$ dose Rs. $15,000,3^{\text {rd }}$ dose Rs. $50,000,4^{\text {th }}$ dose was also Rs. 50,000. And other loans were -c) VO's loan amounting to Rs. 60,000, and d) SthreeNidhi loan of Rs. 50,000. Thus her total loan from different sources was to the tune of Rs. 2,30,000 and net monthly earning was in the range of Rs. 13,000 to 15,000 .

\section{Conclusion:}

These cases glaringly reveal the fact that, rural women are having the entrepreneurial skill, if they are guided properly with financial support. The noteworthy point of the study including field observation is that the women were more interested in loan than subsidy. With earning of income they felt empowered also as in almost all cases their husbands used to take their suggestions in major family affairs and decision. Further, because of women members' earning, the children could pursue good education and thus quality of life of the family had improved.

\section{Acknowledgement}

The author extends his grateful thanks to Sri Chandra Mohan Reddy, Project Director, DRDA, Nizamabad; T. Bhoomeshwar Goud, Assistant Project Manager, DRDA and staff members for their cooperation in carrying out the field study as well as providing data.

\section{References:}

1. https://en.wikipedia.org/wiki/Nizamabad_district

2. www.census2011.co.in/census/district/nizamabad.html

3. https://www.streenidhi.telangana.gov.in

4. FAO, 1992, "Glossary of terms for agricultural insurance \& rural finance"

5. http://www.iaspaper.net/women-empowerment-in-india.

6. UNDP "Human Development Report 2013". 


\section{Appendix}

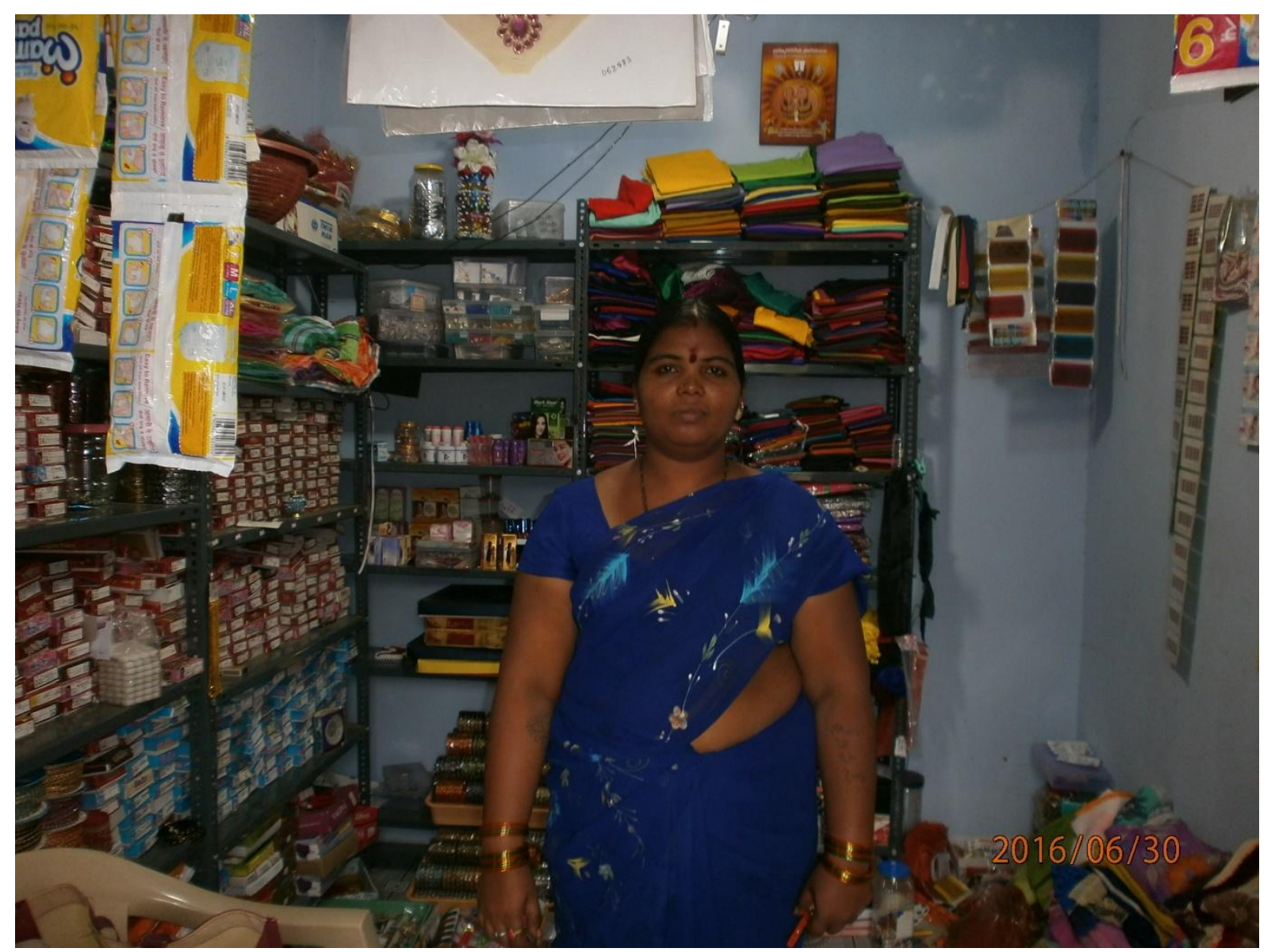

Image 1 


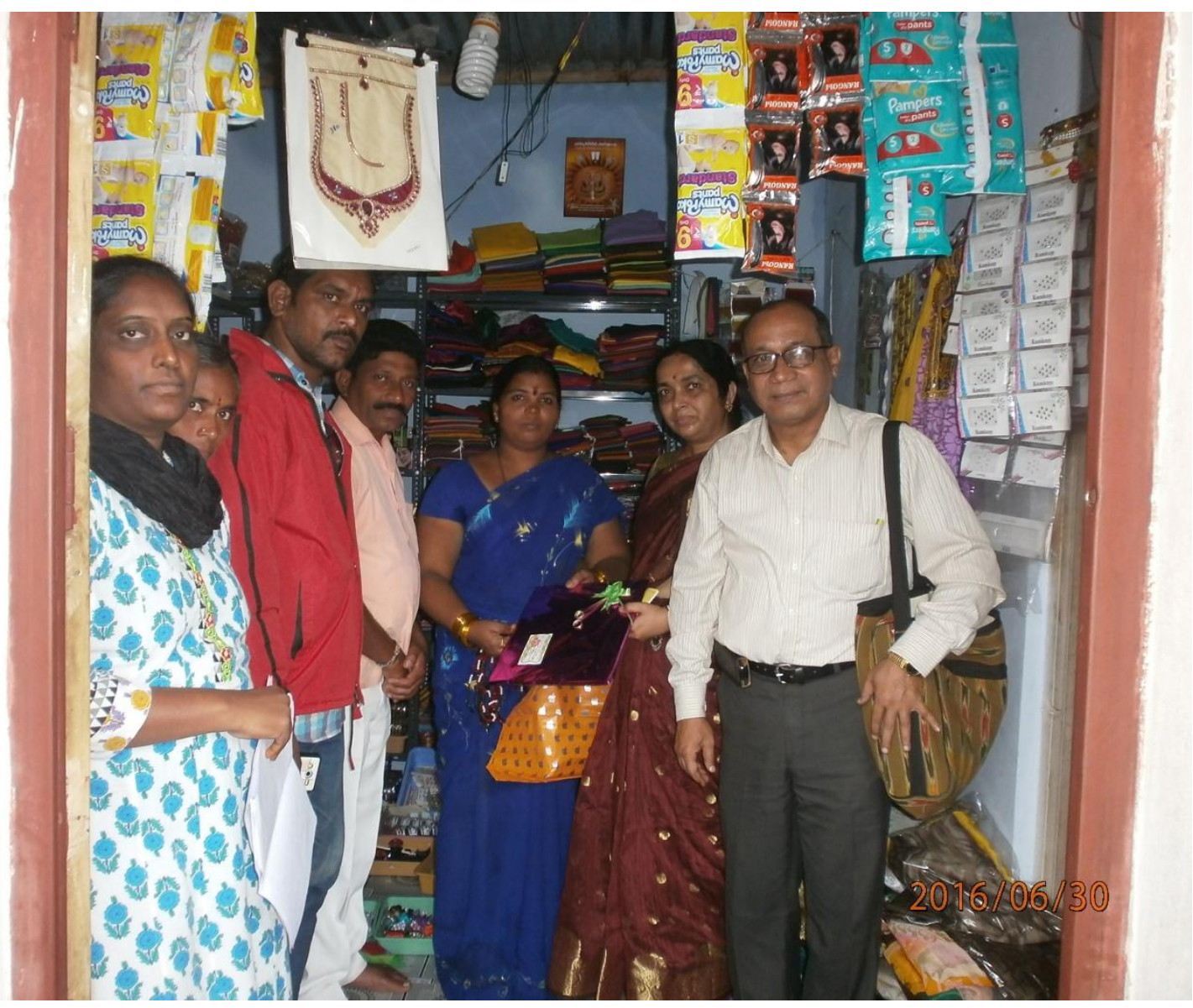

Image 2 


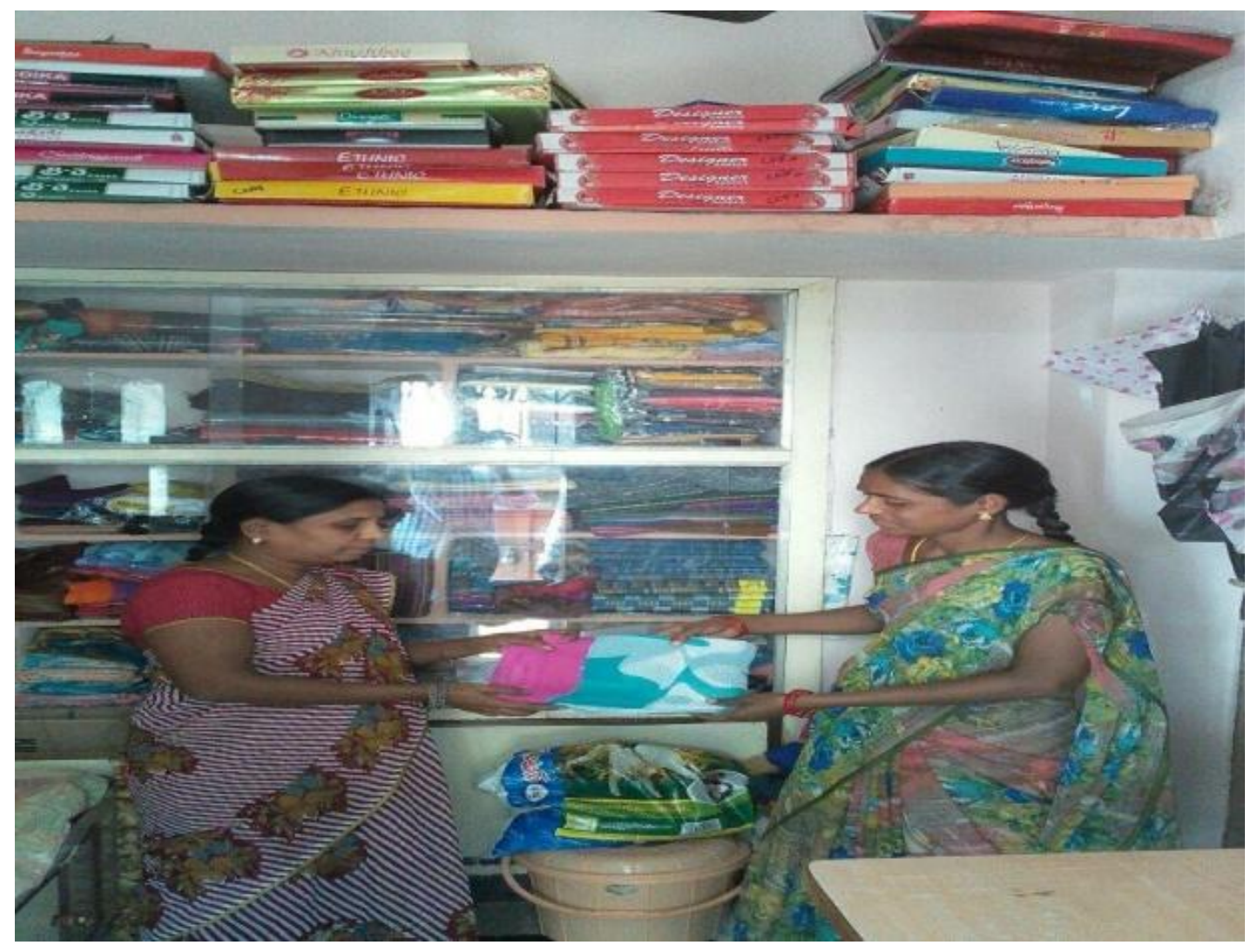

Image 3 


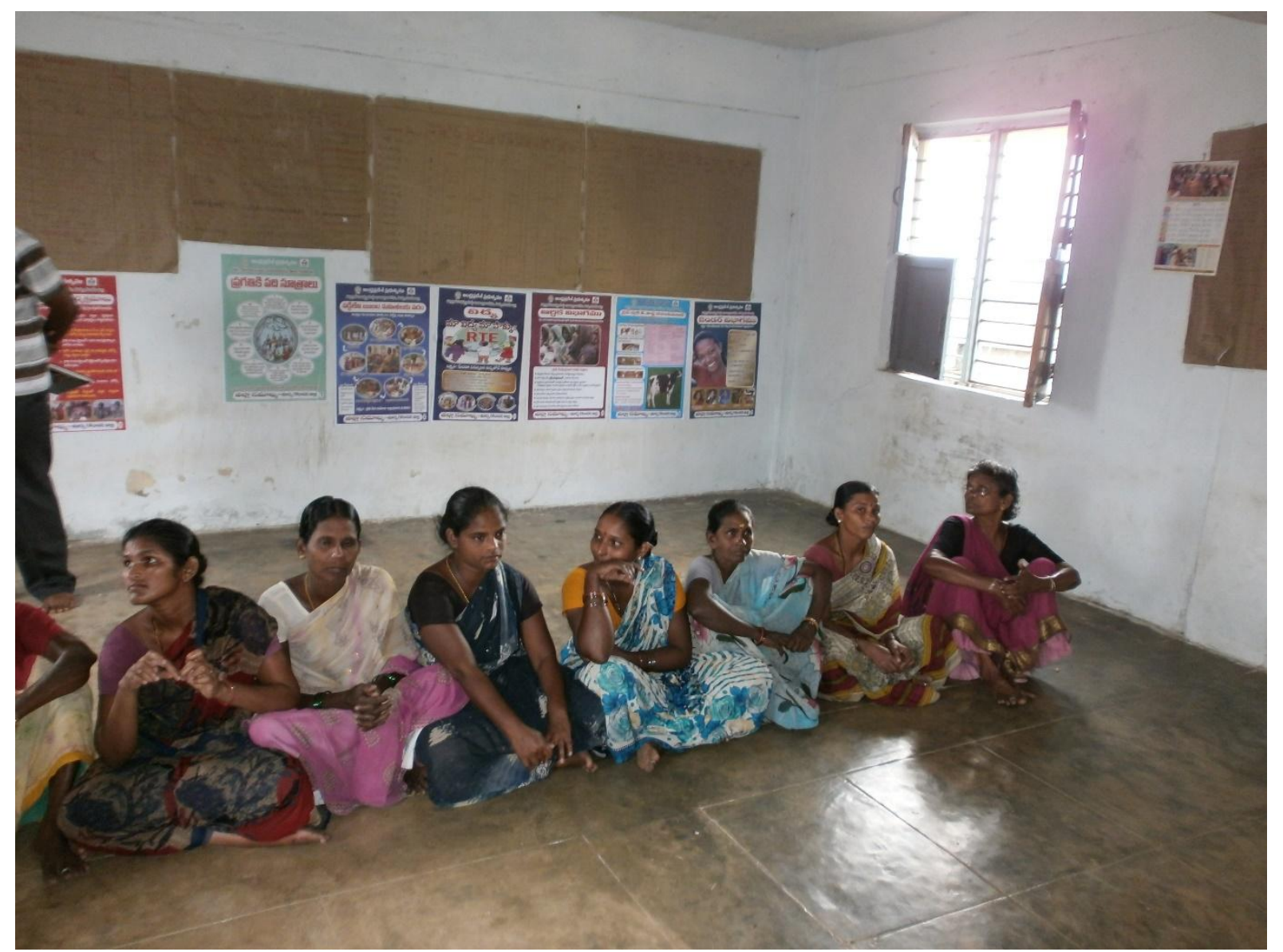

Image 4 


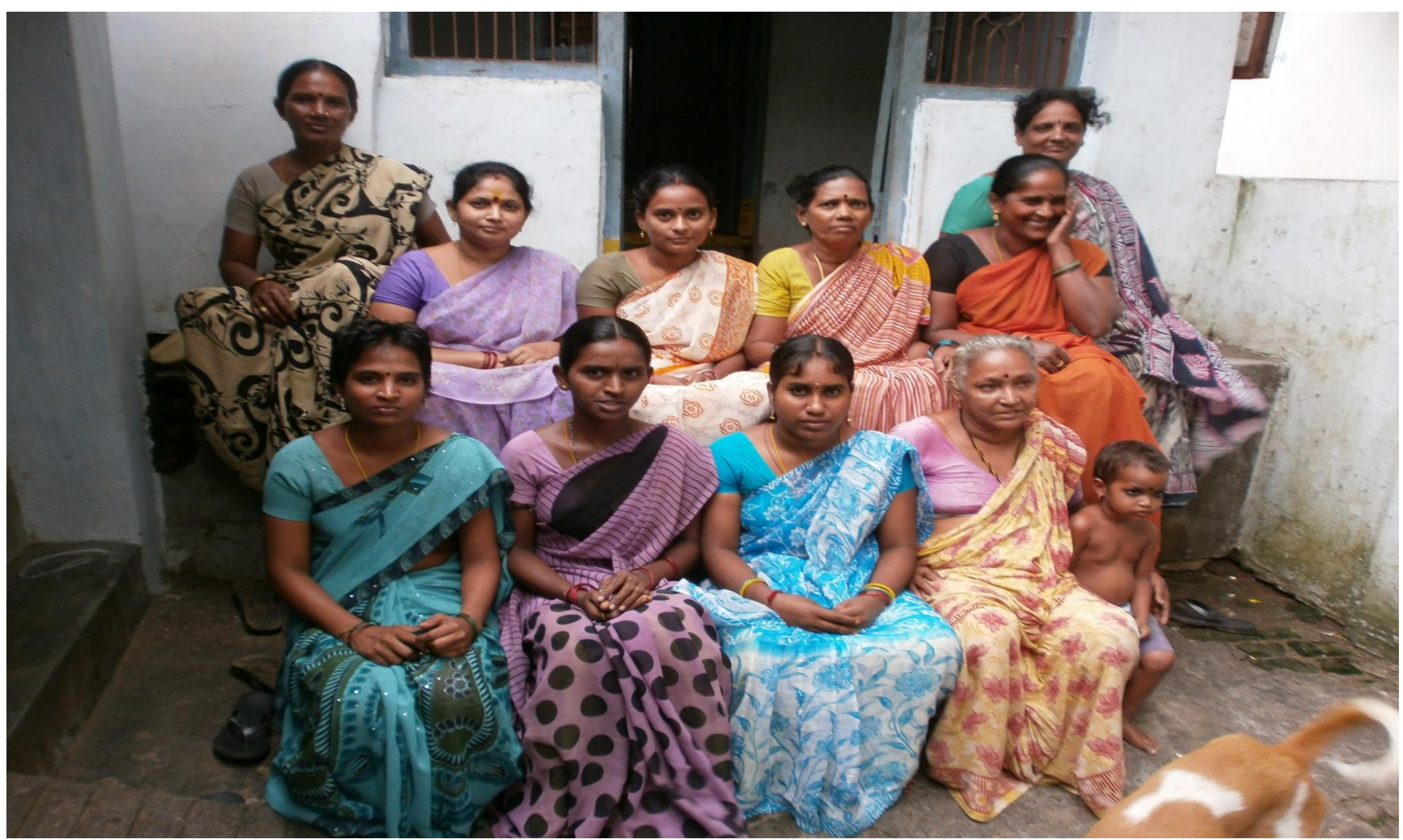

Image 5 


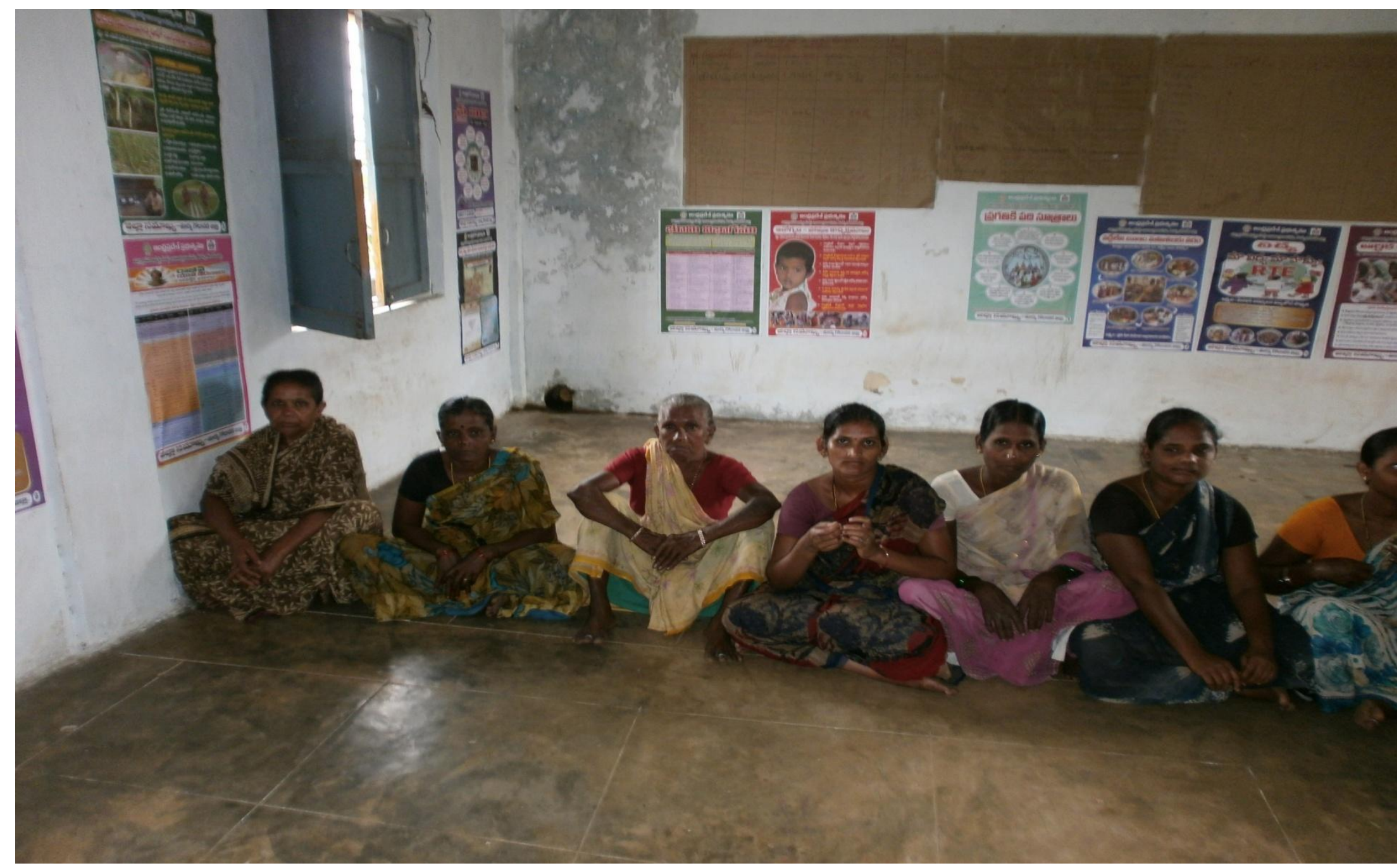

Image 6 


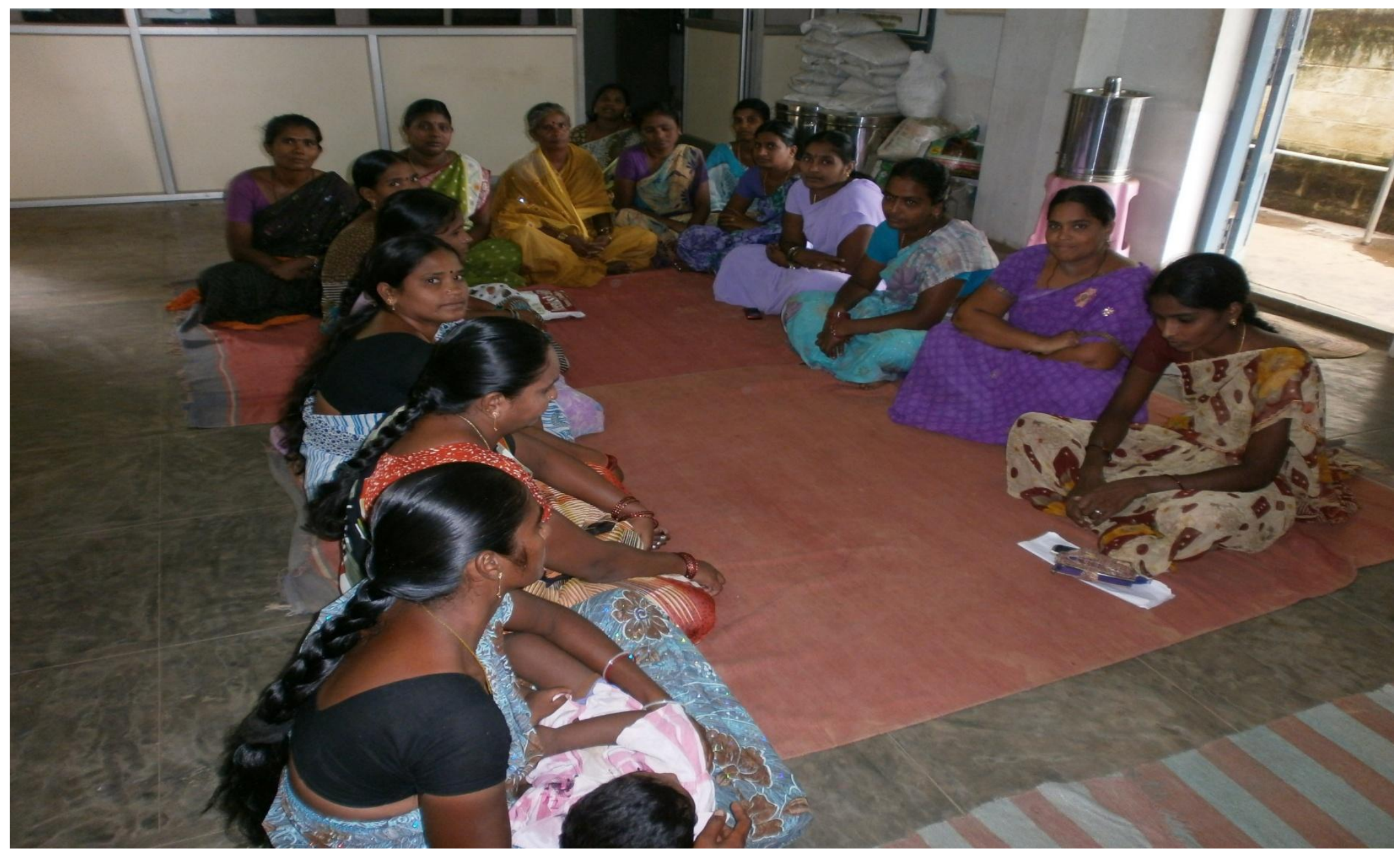

Image 7 


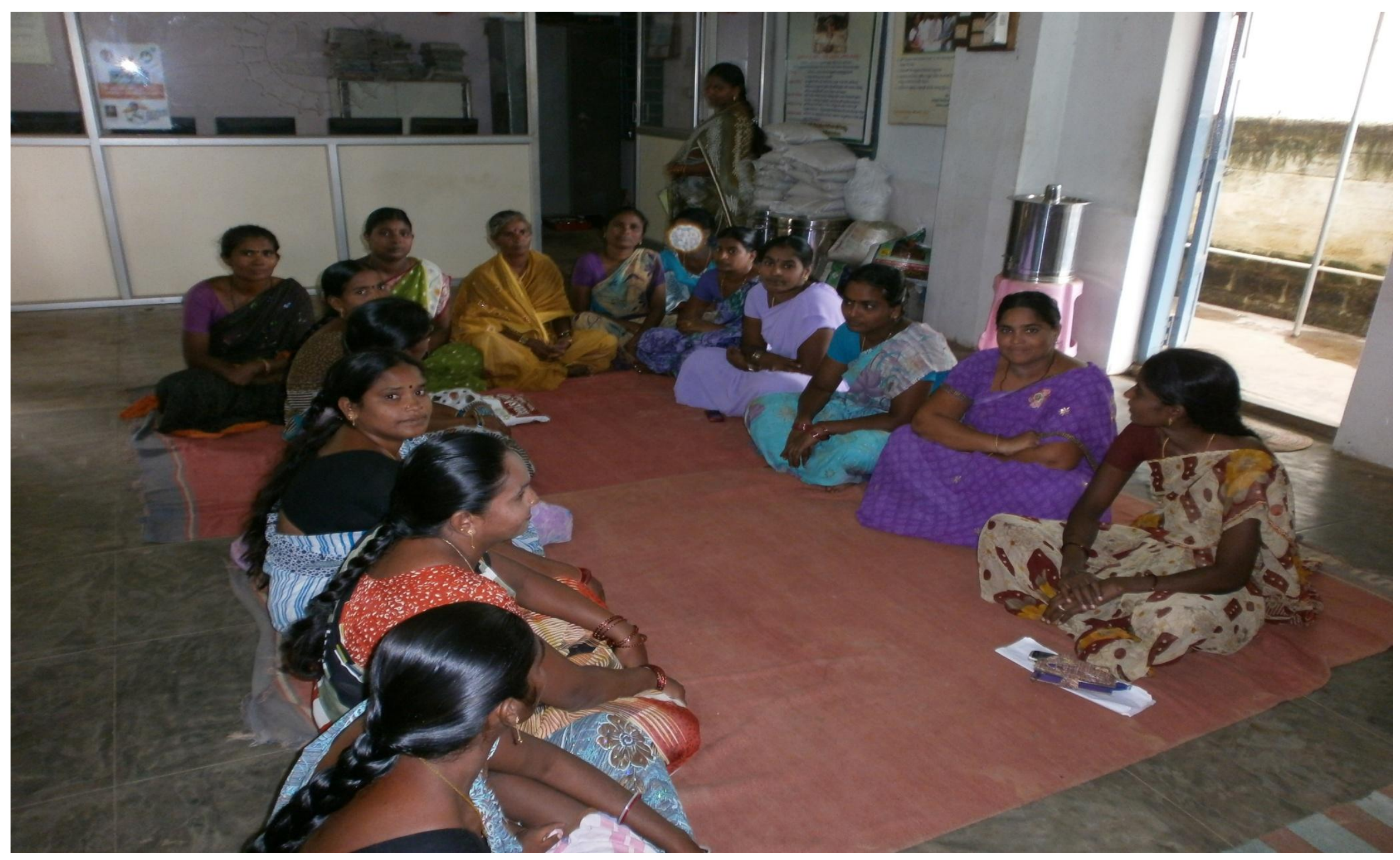

Image 8 


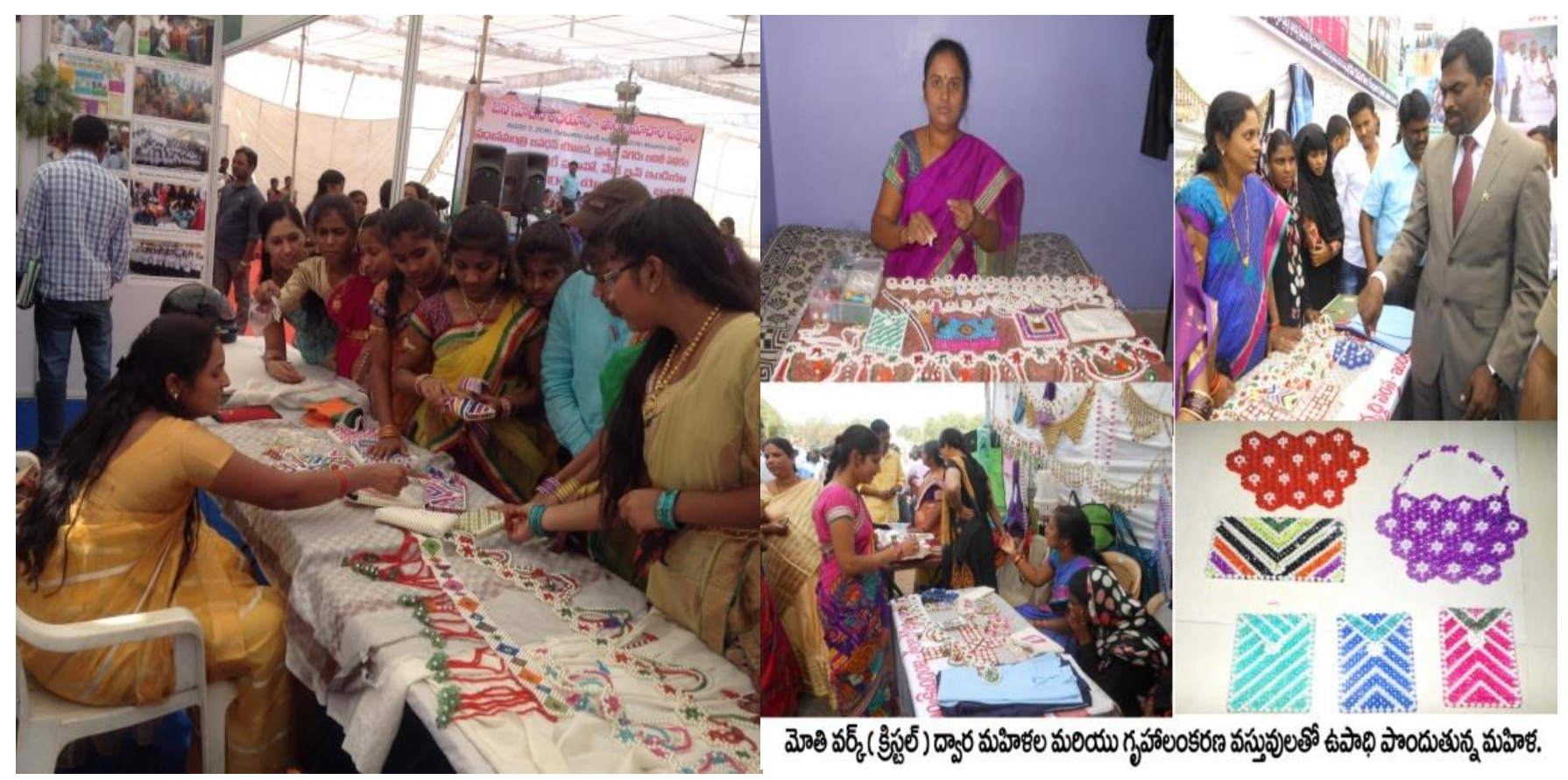

Image 9

Image 10 


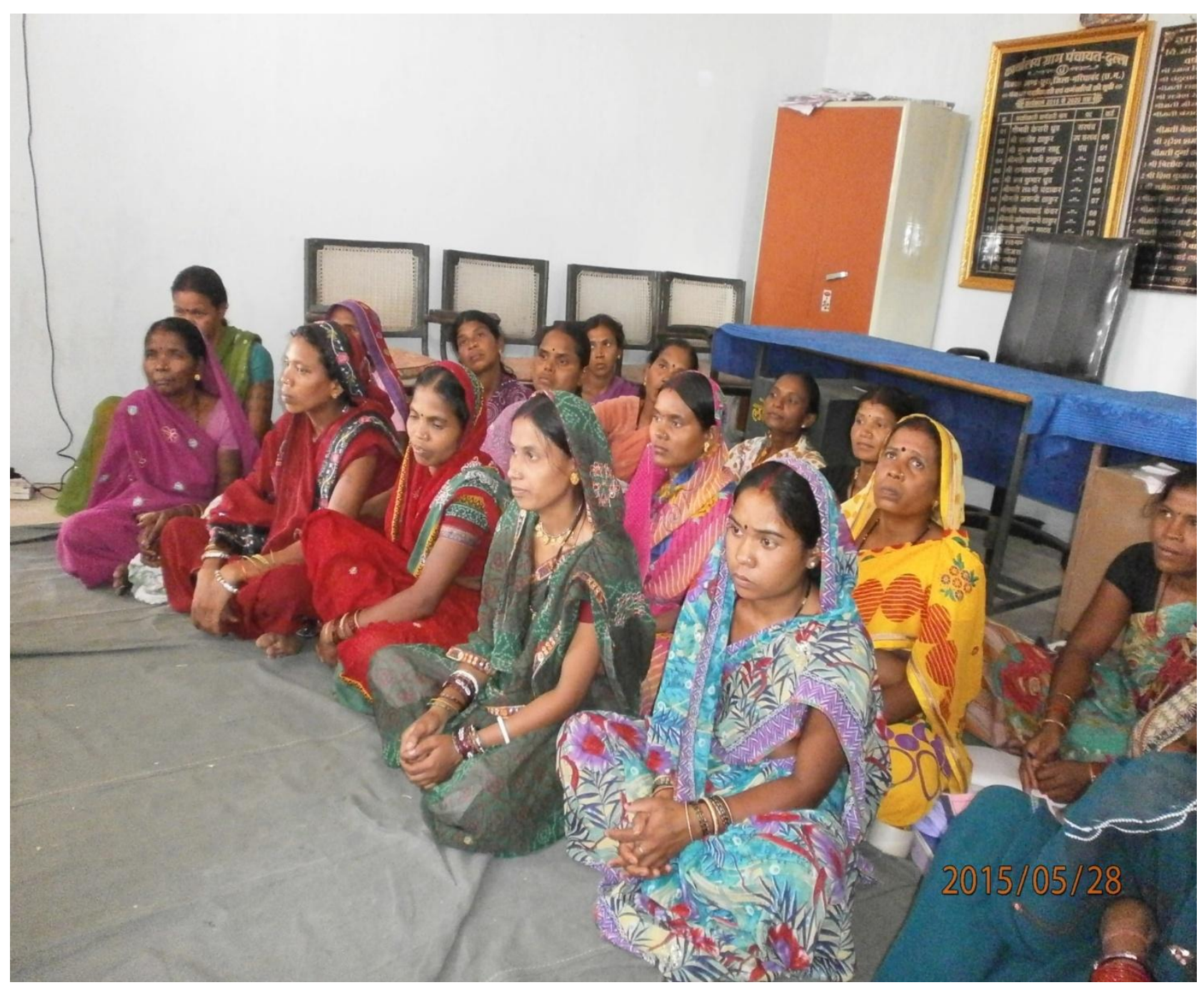

Image 11 